\title{
IAMJ
}

INTERNATIONAL

AYURVEDIC

MEDICAL JOURNAL

\section{THE IMPORTANCE OF YAVAGU IN CLINICAL PRACTICE}

\section{$\underline{\text { Remya }}^{1}, \underline{\text { K Sundaran }}^{2}, \underline{\text { Jishnu R }}^{3}$, $\underline{\text { Athri S. S }}^{4}$}

${ }^{1}$ Final Year PG Scholar, ${ }^{2}$ Professor \& HOD, ${ }^{3,4}$ Associate Professor

Dept of Samhitha and Siddhanta, Pankajakasthuri Ayurveda Medical College \& PG Centre, Kattakkada, Thiruvananthapuram, India

Corresponding Author: drremyajp@gmail.com

\section{https://doi.org/10.46607/iamj1009052021}

(Published Online: May 2021)

Open Access

(C) International Ayurvedic Medical Journal, India 2021

Article Received:10/04/2021 - Peer Reviewed:04/05/2021 - Accepted for Publication:05/05/2021

\section{Check for updates}

\section{ABSTRACT}

Food is a unique tool in the possession of a physician for the maintenance of health as well as the eradication of diseases. Yavagu or medicated gruel (Marunnu Kanji) can be considered as a distinctive food preparation that ought to have a multifaceted approach in the treatment of diseases. Even today the food preparation Kanji is popular, but we have lost the legacy of Marunnu Kanji from our clinical practice due to multiple reasons. The Yavagu preparation can be considered as an advanced form of nutraceutical. What we can do now to restore the practice of Marunnu Kanji Prayogam is to modify the preparation to make it suitable and easy for op practice. Yavagu is very useful in clinical practice because it will increase the palatability of even the bitterest drug, when introduced as Kanji. Also depending on the Yukti of the practitioner, one can advise to increase or decrease the dosage of the specific drug. This article attempts to highlight the importance of the Yavagu or Marunnu Kanji Prayogam by referring to 28 Yavagus mentioned in the Apamargatanduliya Adhyaya.

Keywords: Yavagu, Marunnu Kanji, nutraceutical

\section{INTRODUCTION}

Food upholds a unique position in Ayurveda. It is regarded one of the pillars of life along with Nidra and
Brahmacharya. Food is heralded as Mahabhesaja itself. In the Trisraishaneeya Adhyaya of Charaka 
Samhitha, Yuktivyapasraya Chikitsa is defined as 'Aharaoushadadravyanam yojana'. Again, while referring to the Upasaya, Acharya Madhava defines it as 'Oushadannaviharanamupayogam sukhavaham'. From all these references we are able to catch the glimpse of food becoming a unique tool in the possession of a physician, for the maintenance of health as well as the eradication of disorders.

Yavagu or medicated gruel (Marunnu Kanji) can be considered as a distinctive food preparation that ought to have a multifaceted approach in the treatment of diseases. It is an age-old treatment tradition that has lost its value with the passage of time. Although mentioned in the second chapter of Charaka Samhitha, it should rather be considered as an undermined section in Ayurveda. This statement may be countered with an argument supporting the general assertion that Yavagu is administered as a part of Peyadi Krama. But Peyadi Krama includes Peya, Vilepi, Kritayoosha, Akritayoosha, Kritamamsarasa and Akritamamsarasa. That too is mentioned only in the context of Vamana and Virechana. Hence if the author has mentioned it in the beginning of the text, it should be thought as having a much wider perspective.

The term Yavagu has been referred to by Acharya Susruta in the context of Aharavidhi in chapter 46 of Sutrastana. Hence, we should assert the fact that $\mathrm{Ya}$ vagu is an Aharakalpana only. But Marunnu Kanji Prayogam as part of treatment was a popular tradition in southern states of India, especially Kerala. They are medicated gruels, i.e. the gruels that are prepared with medicines. For years, this Marunnu Kanji Prayogam was so prevalent in the history of traditional practice. This was so easy to prescribe because the Kanji or gruel constituted staple food of most households then.
Even today the food preparation Kanji is popular, but we have lost the legacy of Marunnukanji from our clinical practice due to multiple reasons. Whether a simple Marunnu kanji or medicated gruel is effective in treating diseases is a possible doubt. But in Charaka Samhitha itself, it is mentioned as 'Vividhanamvikaranam tat sadhyanamnivruttaye ${ }^{2}$ i.e. it is capable of eradicating diseases that are Sadya. This article attempts to highlight the importance of the Yavagu or Marunnu Kanji Prayogam by referring to 28 Yavagus mentioned in the Apamargatanduliya adhyaya.

\section{Methodology}

The entire matter for writing this article was obtained from classical Ayurvedic texts. The collected data has been closely analyzed and discussed here.

\section{Result}

The qualities of yavagu as quoted in Sarngdhara Samhita are 'yavagugrahinibalyatarpanivatanasani'. None of the Acharyas mention about the dosage of Yavagu. It has to be determined according to the logic of the physician considering the state of the patient'Dosamagnibalavayavyadhidravyam cha kostam cha veekshyamatraamprayojayet'.

Yavagu and peya are mentioned synonymously by Acharya Susrutha in Aharavidhiadhyaya- 'Peyaityavagu'. The properties of Peya have been mentioned as 'Swedagnijananilaghvideepanivastisodhani, ksuttrtsramaglaniharipeya vatanulomani'3. The only difference between Yavagu and Peya is the difference in the amount of water used to prepare both. The ratio of rice and water in Yavagu and Peya is 1:6 and 1:14 respectively. Correspondingly, the amount of water that will be in the residue after preparation will also be in similar ratio.

\section{Superiority of Yavagu}

Yavagu consists of two parts- Grains and medicinal drugs.

\section{Grains}

Stabilize metabolism in case of sluggish digestion

Starch 75\%-resistant starch with low glycemic index

Glucose level higher than ORS

\section{Medicinal Drugs}

Bioavailability- The proportion of drug or other substance when enters the circulation when introduced into the body and so is able to have an active effect. 


\section{Yavagu as Sabhakthaoushada}

'Sabhaktamyatannaenasamamsadithampaschatva avaloditam '4-Sabhaktha means administering medicine with food. It can be added during or after preparation of food. Thus, Yavagu can be considered as administering medicine during Sabaktaoushadakala.

Nutraceutical- Nutrient + Pharmaceutical

"Nutraceutical" is a substance that may be considered a food or part of a food which provides medical or health benefits, encompassing prevention and treat- ment of disease. It consists of 4 types- dietary supplement, pharmaceutical, medical food and functional food. Medical food is formulated to be consumed or administered internally, under the supervision of a qualified physician. Its intended use is as a specific dietary management of a disease or condition. In compliance with the definition of medical food, the Yavagu preparation can be considered as an advanced form of nutraceutical.

\section{Yavagu in Apamargatanduliya Adhyaya}

\begin{tabular}{|c|c|c|}
\hline No & Action & Drugs used in Yavagu preparation \\
\hline 1 & Deepana Shoolagna & Pippali, Pippalimoola, Chavya,Chitraka,Nagara \\
\hline 2 & Pachana Grahipeya & Kapitha, Vilwa, Charngeri, Takra, Dadima \\
\hline 3 & Vata atisara hara peya & Stirathipanchamoola (Brhati, Kantakari, Shalaparni, Prishniparni, Gokshura) \\
\hline 4 & Pitakapha atisara hara peya & Salaparni, Bala,Vilwa, Prishniparni,Dadima \\
\hline 5 & Raktaatisara hara peya & Chaga payas $+1 / 2$ water, Hribera, Utpala, Nagara, /Prishniparni \\
\hline 6 & Amaghnapeya & Ativisha, Nagara, Dadima \\
\hline 7 & Mutrakrichra hara peya & Swadamshtra,Kantakari,Phanitam \\
\hline 8 & krimighna & $\begin{array}{l}\text { Vidanga, Pippalimoola, Sigru, Maricha, Takra, } \\
\text { Suvarchika (Sarjikakshara) }\end{array}$ \\
\hline 9 & Pipasagna & Mridweeka, Sariba, Laja, Pippali, Madhu, Nagara \\
\hline 10 & Vishagna & Somaraji \\
\hline 11 & Brmhana & Varahaniryooha \\
\hline 12 & Karsaneeyanam & Gavedhukannam + Makshika \\
\hline 13 & Snehana & Taila, Ghee, Lavana \\
\hline 14 & Virookshana & Syaamaka, Kusa Amalaka Niryooham \\
\hline 15 & $\begin{array}{l}\text { Kasa, Hikka, Swasa, Kapha } \\
\text { hara }\end{array}$ & $\begin{array}{l}\text { Dasamoola (Vilwa, Agnimantha,Syonaka, Gambhari, Patala, Prsniparni, Salapar- } \\
\text { ni,Brhati, Kantakari, Gokshura) }\end{array}$ \\
\hline 16 & Pakwasayarujapaha & Madira yamaka \\
\hline 17 & Varchonirasyati & Saka, Mamsa, Tila, Masha \\
\hline 18 & Sangrahana & Jambu, Amrasti, Amla Kapitha ,Vilwa \\
\hline 19 & Bhedana & Yavakshara, Chitraka, Hingu, Amlavetasa \\
\hline 11 & Anulomana & Abhaya., Pippalimoola, Viswa \\
\hline 21 & Ghritavyapatnasana & Takra \\
\hline 22 & Tailayapatnasana & Takrapinyaaka (Tilakalka) \\
\hline 23 & Vishamajwaranasani & Gavyamamsarasa, Dadima \\
\hline 24 & Kantya & Yava, Yamaka (Bharjana), Pippali, Amalaki \\
\hline 25 & Retomargarujapaha & Tamrachoodarasa \\
\hline 26 & Vrishya & Vidalamashaghrita, Kshira \\
\hline 27 & Madavinashana & Upodika (Basella Rubra), Dadhi \\
\hline 28 & Kshuthanyat & Apamarga, Kshira, Godharasa \\
\hline
\end{tabular}

testify the efficacy of Yavagu especially in Kostagatarogas.

If we go through the indicated diseases of the various above given Yavagu, we can see that most of them are Kostagatarogas. Those who practice Marunnukanji

\section{DISCUSSION}

Yavagu or Marunnu Kanji Prayogam was prevalent in our society for a long period of time. But subsequently 
this tradition disappeared from the arena and was replaced by readily available over the counter therapies. Moreover, the derailing of Ayurvedic physicians and the booming acceptance of modern medicine in our society, to establish the magnitude of Ayurveda physicians stuck on to complex therapies and formulations rather than these simple medicinal recipes. However, some of the medicines like Aviltoladi bhasma to prepare Yavagu are still available in market. This indicates that many physicians still practice it, even though much lesser in number.

Need of the hour

"Modifying the procedure of preparation"

What we can do now to restore the practice of Marunnu Kanji Prayogam is to modify the preparation to make it suitable and easy for op practice. Here we have to remember the quotation From Astanga Samgraha- 'Yavatamuktarasata' 5 in the context of Kashaya preparation i.e. while preparing Kashaya the Dravya has to be boiled in water until the Kalka loses its taste. This indicates that the medicine has diffused properly into the water. Keeping this in mind, we can ask the patient to take the rice (according to one's suitability) and the required amount of water to cook it. We can ask them to prepare a Potali or Kizhi of medicines. Put the Kizhi in water and start boiling. Once the water starts boiling, remove the Kizhi and put rice. Then reintroduce Kizhi. The time taken to cook the rice will be enough and more to get the essence of the drug in the water. This way the process seems simpler and can be effectively communicated to the patient or the care giver.

The above mentioned procedure is doable now, since most of the drugs mentioned in Marunnu Kanji Prayogam are Mrdu Dravyas. Even if we have to use Katina Dravyas like Patala etc., they are available in smaller pieces or even coarse powder nowadays.
In many of the Yavagu, buttermilk has been mentioned. Here we should not add it in the beginning because it will curdle. Hence after preparing Marunnu Kanji with rest of the drugs, we can add buttermilk at the end. This way it won't curdle. Also, Yavagu gives the physician the freedom to determine the amount of the individual drugs used to suit one's palatability as well as the strength of the Roga and the Rogi.

\section{CONCLUSION}

Yavagu is very useful in clinical practice because it will increase the palatability of even the bitterest drug, when introduced as Kanji. Also depending on the Yuk$t i$ of the practitioner, one can advise to increase or decrease the dosage of the specific drug. Yavagu has been testified as extremely effective in curing Kostagatarogas. Hence it is the duty of the budding doctors to identify its importance and to incorporate it in clinical practice before the legacy is lost.

\section{REFERENCES}

1. Acharya Vaidya Yadavji Trikamji, editor, Charakasamhita of Agnivesha, Sutrasthana Ch.11 ver54. reprint edition, Varanasi. Chaukambha orientalia, 2015

2. Acharya Vaidya Yadavji Trikamji, editor, Charakasamhita of Agnivesha, Sutrasthana Ch.2 ver27. reprint edition, Varanasi. Chaukambha orientalia,2015

3. Kaviraja Dr. Ambika DuttaShastri, editor, Sushruta Samhita edited with Hindi Commentary Ayurved Tatva Sandipika, Sutrastana-Ch-46 ver 342.Chaukhamba Sanskrit Sansthan. Varanasi,2003

4. Vagbhata. In: Ashtanga Sangraha, Sutra Sthana, Bheshajaavacharniya Adhyaya, 1st edition. Sharma SP, editor. Varanasi: Chaukambha Sanskrit Series Office; 2006

5. Vagbhata. In: Ashtanga Sangraha, Kalpa Sthana, $8^{\text {th }}$ chapter, 1st edition. Sharma SP, editor. Varanasi: Chaukambha Sanskrit Series Office; 2006

\section{Source of Support: Nil \\ Conflict of Interest: None Declared}

How to cite this URL: Remya $J$ et al: The Importance Of Yavagu In Clinical Practice. International Ayurvedic Medical Journal \{online\} 2021 cited May, 2021\} Available from: http://www.iamj.in/posts/images/upload/1007 1010.pdf 